Egyptian Journal of Aquatic Biology \& Fisheries

Zoology Department, Faculty of Science,

Ain Shams University, Cairo, Egypt.

ISSN $1110-6131$

Vol. 24(4): $391-407$ (2020)

www.ejabf.journals.ekb.eg

\title{
Positive Effects of Meso -2, 3-Dimercaptosuccinic Acid against Oxidative Stress of Lead and Mercury in the Catfish Clarias gariepinus of Lake Maryout, Egypt
}

\author{
Awatef M. Ali, ${ }^{1}$ Nema A. Mohamed ${ }^{1}$, Shnoudy A. Bakhoum ${ }^{2}$, \\ Heba H. Abdel-Kader, Mohamed A. Ahmed ${ }^{2}$ \\ ${ }^{1}$ Department of Zoology, Faculty of Science, Alexandria University, Alexandria, Egypt. \\ ${ }^{2}$ National Institute of Oceanography and Fisheries, NIOF, Egypt. \\ *Corresponding author: hebaelalkamy3232@gmail.com
}

\section{ARTICLE INFO}

Article History:

Received: April 22, 2020

Accepted: May 30, 2020

Online: June 2020

Keywords:

Clarias gariepinus, Lake Maryout,

Heavy metals,

DMSA,

Gills,

Gonads

\section{ABSTRACT}

This investigation evaluated the effects of $\mathrm{Pb}$ and $\mathrm{Hg}$ in Lake Maryout on Clarias gariepinus fish with reference to the effect of meso-2, 3 dimercaptosuccinic acid (DMSA). Fishes divided into Standard group (10 fish) caught from the lake and directly anesthetized to carry out flesh composition and histopathological examination on gills and gonads. An Experimental -group (60 fish) supplied with lake water and divided into sub-group $\mathbf{A}$ without treatment, sub-group B, supplied with $5 \mathrm{mg} / \mathrm{kg}$ b.w / L of DMSA, sub-group C, supplied with $18 \mathrm{mg} / \mathrm{kg}$ b.w/L of DMSA. After 60 days, fish get the same examination as a standard group. A significant decrease in water content for subgroup B\& C, sub-group $\mathrm{C}$ with low lipid comparing with sub-group B. Protein levels were significantly increased in both sub-group B\&C than sub-group A. The standard gill showed loss of integrity of lamellae and filaments with capillary congestion. Sub-group A showed brachial lesions with the disappearance of the normal architecture. Sub-group B showed middle improved tissues with an organized pillarcellsystem. In sub-group C, filaments had normal architecture with two rows of secondary lamellae perpendicular to each filament. Standard ovaries showed wrinkling pre-vitologenic, vacuolated late pre-vitologenic, and degenerative vitologenic oocyte. Sub-group A showed few stages of oocytes and wide inter-follicular space. Sub-group B showed some stages of oocytes. Sub-group $\mathrm{C}$ showed all stages. Standard testes showed degenerative cellular elements in most seminiferous tubules with dilated congested blood vessels. Sub-group A showed distortion of testicular architecture. Sub-group B showed moderate improvement in testicular pictures. Sub-group C showed organized tubules with all stages. In conclusion, the protective effect of DMSA may be attributed to its activity as a chelating agent with two negatively charged groups that allow it to form complexes with multiple positive charges metal ions as $\mathrm{Pb}$ and $\mathrm{Hg}$ and reactive oxygen species.

\section{INTRODUCTION}

Pollutants from industrial and agricultural operations find their way into the natural water resources and affect the aquatic organism (Mary et al., 2014). The lakes are arranged 
according to the levels of pollution in which Lake Maryout> Lake Manzalah> Lake Edku> Nozha Hydrodrome> Lake Brollus (Saad, 2003). Heavy metals cannot be metabolized and will not break down into harmless forms since they leave biological cycles very slowly (Abumourad et al., 2013). Dissolved metals occur naturally in trace amounts in the aquatic environment, they may be transported, concentrated, changed into other forms and are reintroduced into the aquatic system as contaminations (El-Boshy et al., 2014). Many dissolved metals that enter the aquatic ecosystem are adsorbed into colloid particles caused water pollution problems (Damian et al., 2014).

Lead and mercury are referred to as "heavy metals"(Pugazhvendan $\boldsymbol{e t}$ al., 2012) and if present in high concentrations could have a negative effect on both the river system and fish population (Shalaby and El Migeed, 2012). Lead has adverse effects on the gill of tilapia and catfish species (El-Shehawi et al., 2014); African catfish (Clarias gariepinus) (Mary et al., 2014); freshwater fish (Cirrhinus mrigala) (Mokhtar and Abd-Elhafeez, 2013). Mercuric chloride has histological effect of on gill structure of freshwater fish (Clarias Batrachus (Linn.) (Selvanathan et al., 2012); freshwater female crab (Barytelphusa cunicularis) (Westwood) (Chourpagar and Kulkarni, 2014) where the degree of distortion of the gill was proportional to the exposure period and concentration of the metals (Selvanathan et al., 2012). Gill tissues are considered as the main site for heavy metal uptake and its excessive intake can easily become the cause of fish death by causing the precipitation of mucous on the gill surface membrane (Siraj et al., 2014).

The oocyte development of the gonads (testes and ovaries) of grey mullet Liza ramada and the sea bass (Dicentrarchuslabrax) from Lake Manzalah showed marked degenerative changes after pb exposure (El-Morshedi $\boldsymbol{e t}$ al., 2014). The gonads of teleosts are affected by $\mathrm{Pb}$ pollutions that in turn effect on reproductive behavior of Oreochromis niloticus (Mokhtar and Abd-Elhafeez, 2014). There was marked degenerative changes in the ovaries of African catfish Clarias gariepinus exposed to mercuric chloride (Masarat $\boldsymbol{e t}$ al., 2014).

Chelating agents are capable of binding to toxic metal ions to form complex structures which are easily excreted from the body, e.g.. meso-2, 3-dimercaptosuccinic acid (DMSA) (Flora and Pachauri, 2010). DMSA is a water soluble, safe and effective chelator (Bradberry and Vale, 2009). Most DMSA in plasma is protein (mainly albumin)bound through a disulfide bond with cysteine; a very small amount is present as free drug, which is filtered at the glomerulus then reabsorbed into proximal tubule cells. Non-filtered protein-bound DMSA in peri-tubular capillaries is also available for uptake into proximal tubule cells by active anion transport at the basolateral membrane (Flora $\boldsymbol{e t}$ al., 2008). DMSA accumulates in the kidney where it is metabolized in humans to mixed disulfides of cysteine. Some $10-25 \%$ of an orally administered dose of DMSA is excreted in urine, the majority within $24 \mathrm{~h}$ and most (>90\%) as DMSA-cysteine disulfide conjugates (Bradberry and Vale, 2009). 
Palaniappan et al. (2009) examined the morphological changes on the gill of the C. catla fingerlings due to $\mathrm{Pb}$ intoxication and the effect of DMSA on the affected tissues. Also, Raafat et al. (2011) showed the protective effect of DMSA and vitamins C in histological characteristics in rabbit. El-Sayed et al. (2015) studied the ameliorative effects of DMSA and some vitamins against toxicity induced by $\mathrm{Pb}$ in albino rat's testes.

The present study aimed to investigate the role of low and high dose of DMSA against the toxicity of lead and mercury in waste water from Lake Maryout, Alexandria, Egypt on gills and gonads of the catfish (Clarias gariepinus) which expressed as histopathological scores.

\section{MATERIALS AND METHODS}

\section{Experimental design}

The antidote DMSA is a white powder with molecular weight 182.21, it was obtained from ACROS Organics Company, USA. 70 specimens (both sexes) of C. gariepinus (20 - 23 $\mathrm{cm})$ and $(115 \pm 5.0 \mathrm{~g})$ were caught from the main basin of Lake Maryout in May 2015. Fish were trapped in closed meshed nets, maintained alive and transported to the laboratory in large vessels filled with aerated lake water. Fish maintained at $\left(22^{\circ} \mathrm{C}-30^{\circ} \mathrm{C}\right), \mathrm{pH}(8.0-8.8)$ with biofilters and aeration acclimated to laboratory condition for 15 days, the water from Lake Maryout, was renewed weekly for 60 days. The fish were fed with commercial fish feed, a rate of ( $1.5 \%$ b.w/day).

The fishes were divided into 2 groups: Standard group, included 10 fish caught from the lake water and directly anaesthetized to carry out histopathological examination on gill and gonads. Experimental - group, it included 60 fish which were supplied with lake water and divided into 3-sub groups: sub-group A, without any treatment, sub-group B, supplied with $5 \mathrm{mg} / \mathrm{kg}$ b.w / L of DMSA, sub-group C, supplied with $18 \mathrm{mg} / \mathrm{kg} \mathrm{b.w} \mathrm{/L} \mathrm{of}$ DMSA. After 60 days, fish were anaesthetized to carry out histopathological examination on gill and gonads ( Palaniappan and Vijayasundaram , 2009).

\section{Flesh composition analysis}

Water content in tissues was determined according to methods described by Sidwell et al., 1970. Total lipid content in tissues was determined according to methods described by Knight et al., (1972). Total protein content in tissues was determined according to methods described by Doughaday et al., (1952).

\section{Histological studies}

Gills and gonads were quickly removed; excised, fixed at room temperature overnight in $10 \%$ formalin solution and routinely processed for paraffin embedding. Sections were cut at $3 \mathrm{~mm}$ and stained routinely with Haematoxylin and Eosin according to Bancroft and 
Gamble (2002). The prepared slides were examined under a light microscope using objective lens power (X10, X40, and X100).

\section{Statistical analysis}

Data were tested using one-way ANOVA followed by Tukey honest-significant difference test (TSD), which was used to test for the differences among treatment means when F-values were significant. All collected data in the present study were subjected to statistical analysis by using SPSS 16 software.

\section{RESULTS}

\section{The protective role of DMSA on body flesh composition}

Table (1) showed a significant decrease $(p<0.05)$ in the amount of water content for DMSA exposed fish comparing with the unexposed group. TSD revealed a significant decrease between unexposed fish and high dose exposed group. Moreover, the decreased lipid percentage was found in the high dose DMSA group comparing with fish exposed to low dose DMSA $(p<0.03)$. Protein levels were significantly increased $(F=7.43, p<0.01)$ in the exposed DMSA groups than unexposed groups. Protein percentage was increased in low (TSD, $\mathrm{p}<0.02)$ and high (TSD, $\mathrm{p}<0.01)$ doses of DMSA.

Table 1. Flesh composition of catfish before and after exposure to DMSA

\begin{tabular}{lclll}
\hline Treatments & Standard group & $\begin{array}{l}\text { Unexposed } \\
\text { DMSA group }\end{array}$ & $\begin{array}{l}\text { Low Dose } \\
\text { DMSA group }\end{array}$ & $\begin{array}{l}\text { High Dose } \\
\text { DMSA group }\end{array}$ \\
\hline Water content (\%) & $58 \pm 9.6^{\mathrm{b}}$ & $81.00 \pm 5.38^{\mathrm{a}}$ & $67.80 \pm 9.23^{\mathrm{b}}$ & $67.00 \pm 6.21^{\mathrm{b}}$ \\
Total lipid $(\mathbf{m g} / \mathbf{g})$ & $3.03 \pm 0.47^{\mathrm{ac}}$ & $4.25 \pm 1.17^{\mathrm{a}}$ & $4.28 \pm 0.64^{\mathrm{ac}}$ & $2.68 \pm 0.53^{\mathrm{bd}}$ \\
Total protein(mg/g) & $40.53 \pm 13.04^{\mathrm{d}}$ & $14.64 \pm 5.12^{\mathrm{a}}$ & $28.62 \pm 6.07^{\mathrm{bc}}$ & $30.34 \pm 6.41^{\mathrm{c}}$ \\
\hline
\end{tabular}

Values are expressed as mean \pm SD $(n=10)$ in each group. Means in a row with no common superscripts are significantly different $(P<0.05)$.

\section{Histopathological Examination \\ The protective role of DMSA on gills}

The standard gill section showed slight thickening of primary lamellae, coagulative necrosis, consequent complete fusion occurred occasionally along the entire length of secondary lamellae as a result of hyperplasia of inter-lamellar epithelium (Fig.1), curling and sloughing of secondary lamellae, loss of integrity of lamellae and gill filaments, capillary congestion and wilting of pillar cell system particularly at the distal ends of secondary lamellae (telangiectasia $=$ aneurism) $($ Fig. 2).

In sub-group A, gill section showed the greatest severity and brachial lesions with the disappearance of the normal architecture. The lesions were diffuse and characterized by complete fusion of adjacent secondary lamellae which led to a reduction of the epithelium surface area. The collapse of gill filaments epithelium and shrinkage of the supporting cartilage decreased the size of gill filaments (Fig. 3). Severe hyperplasia with intensive hypertrophy of inter-lamellar epithelium and aggregations of inflammatory cells in gill filaments were well illustrated. Also, gill epithelium was disrupted owing to severe 
degeneration and necrosis in some area with grossly sloughed of gill filament from the base membrane (Fig. 4)

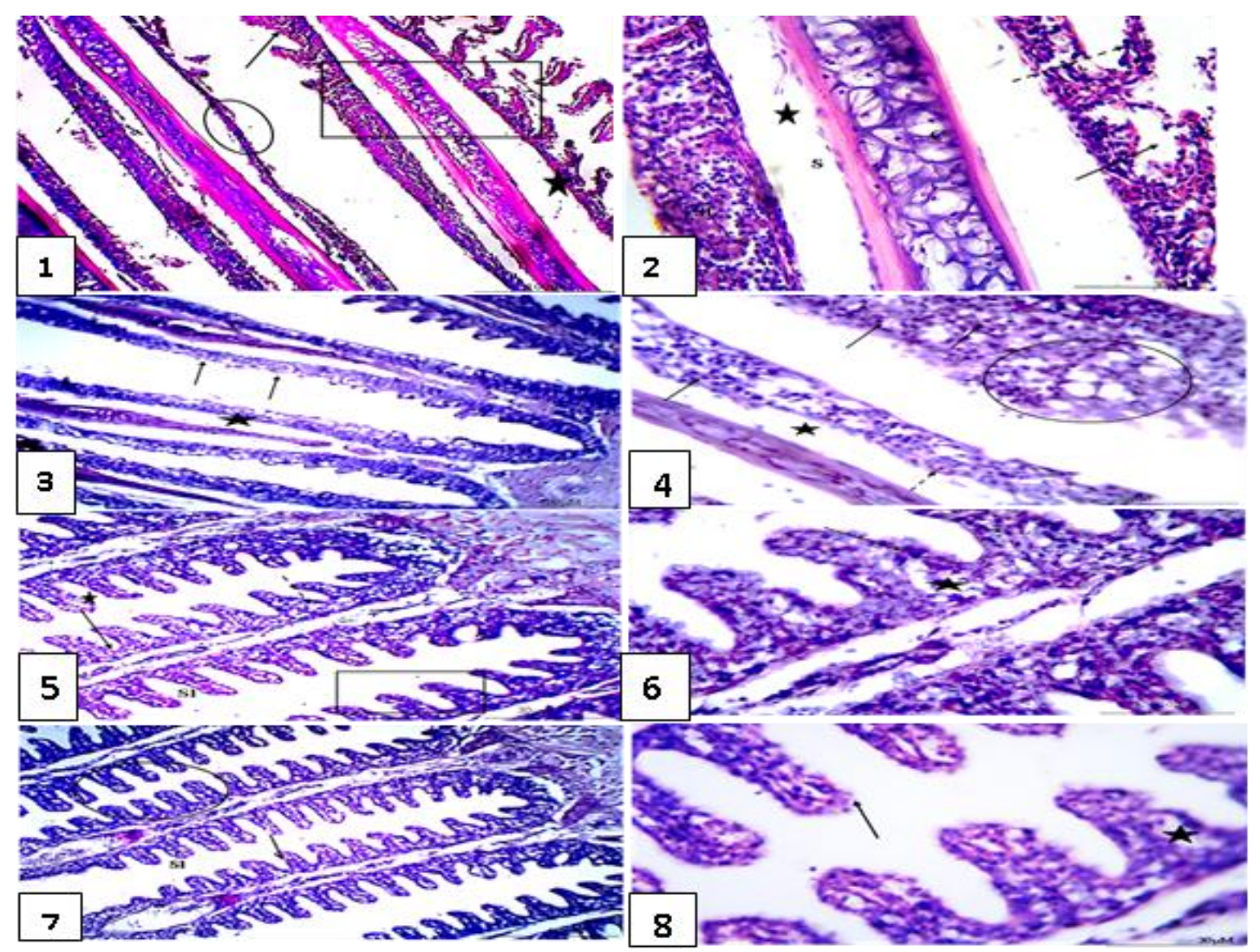

Figs. 1-2: Light micrographs of standard gill sections from main basin (H\&E stain) showing:

Fig. 1: Slight (arrow) and severe thickening (dashed arrow) of primary lamellar epithelium, curling of secondary lamellae (S1), detached gill filament (asterisk). Fig. 2: Enlarged part from figure 1 (square): lifting of lamellar epithelium (asterisk),sub epithelial space (arrow), curling (dashed-arrow) or complete fusion of secondary lamellae (Sl),dilated blood sinusoid (S), deformed cartilage (C).

Figs. 3-4: Light micrographs of gill sections exposed to pollution for 60 days (H\&E stain) showing: Sub-group A

Fig.3: complete fusion of adjacent secondary lamellae (arrows), collapse of gill filaments epithelium (asterisk), deformed cartilage tissues (C). Fig. 4: Complete destruction of secondary lamellae lifting erythrocyte (dashed arrow), intensive hypertrophy of inter-lamellar epithelium (circle), cellular infiltration (arrows), sloughed gill filament (asterisk).

Figs. 5-6: light micrographs of gill sections exposed to pollution + low dose DMSA for 60 days (H\&E stain) showing: SubGroup B

Fig. 5: slightly improved gill tissues with primary (arrow) and secondary gill lamellae (S1), epithelial lifting (asterisk), slight epithelium hypertrophy of secondary lamellae (dashed arrow). Fig. 6: Enlarged part from figure 5 (square): simple epithelium hypertrophy (asterisk), epithelial lifting (arrow), organized pillar cell system (dashed arrow) .

Figs. 7-8: Light micrographs of gill sections exposed to pollution + high dose DMSA for 60 days(H\&E stain) showing: Sub-group C

Fig. 7: Improved gill tissues with large number of primary lamellae (arrow), secondary lamellae (S1) perpendicular to each filament .Fig. 8: Enlarged part from figure7 (circle): improved gill filaments with noral epithelial cells (arrow), slight epithelial lifting (asterisk) . 
The gill section with low dose DMSA (sub-group B) showed low to middle improved gill tissues in which the gill consists of primary and secondary gill lamellae with epithelial lifting and slight hypertrophy of the epithelium at the base of secondary lamellae (Fig. 5). The regular secondary lamellae showed an arrangement of filaments in double rows, simple edematous hypertrophy of covering epithelial cells and epithelial lifting (Fig. 6).

The gill section with high dose DMSA (sub-group C) illustrated spectacular changes in the gills: there was no fusion of secondary lamellae where the primary and secondary lamellae were distinctly identical. Each gill consisted of a large number of primary lamellae on which a series of alternately arranged secondary lamellae are projected (Fig. 7). Gill filaments had an almost normal architecture with two raw of secondary lamellae that were perpendicular to each filament. The primary lamellar epithelium was one or two cell layers thick (Fig. 8).

\section{The protective role of DMSA on gonads}

\section{Ovary}

The standard ovary section showed few stages as early pre- vitologenic oocytes underwent wrinkling, vacuolated late pre-vitologenic oocytes and degenerative vitologenic oocyte (Fig. 9). In addition, the post vitologenic oocyte wall consisted of zona radiata, thick granulose layer as a result of hyperplasia of cuboidal cells and coated with a shrunk follicular epithelial layer. Yolk globules aggregated to form groups or were coalescing to form large granules as indicated in Fig. 10. Unfortunately, ovulation is corrupted.

The ovary section in sub-group A showed more damage in the ovary architecture in comparison with other groups. Deformed ovary with only a few stages includes early previtologenic; many late pre-vitologenic, many collapsed atretic follicle, degenerated late previtologenic oocytes in between wide inter-follicular space (Fig.11). Vacuolated late previttilogenic oocytes, haemorrhage between oocytes exhibiting yellow pigments, vitologenic oocyte with rare yolk globules and vague theca follicle were seen (Fig. 12).

The ovary section in sub-group B showed less to moderately improved ovary with many stages of ovary oocytes including early pre-vitellogenic, late pre-vitellogenic, cortical follicle, deformed vittellogenic follicles (Fig. 13). There was improved vitellogenic oocytes characterized by the presence of a large number of yolk vesicles as circumferential rings in the cytoplasm and yolk globules frequently fill the entire center of the oocyte and a germinal vesicle disappeared (Fig. 14).

The ovary section in sub-group $\mathrm{C}$ showed group-synchronous development of improved stages included early pre-vitologenic with small cytoplasmic volume, many late previtologenic, abundant cortical, vitologenic oocytes with yolk bodies frequently fill the entire center and the post vitologenic oocytes completely filled with a large number of yolk granules (Fig. 15). 


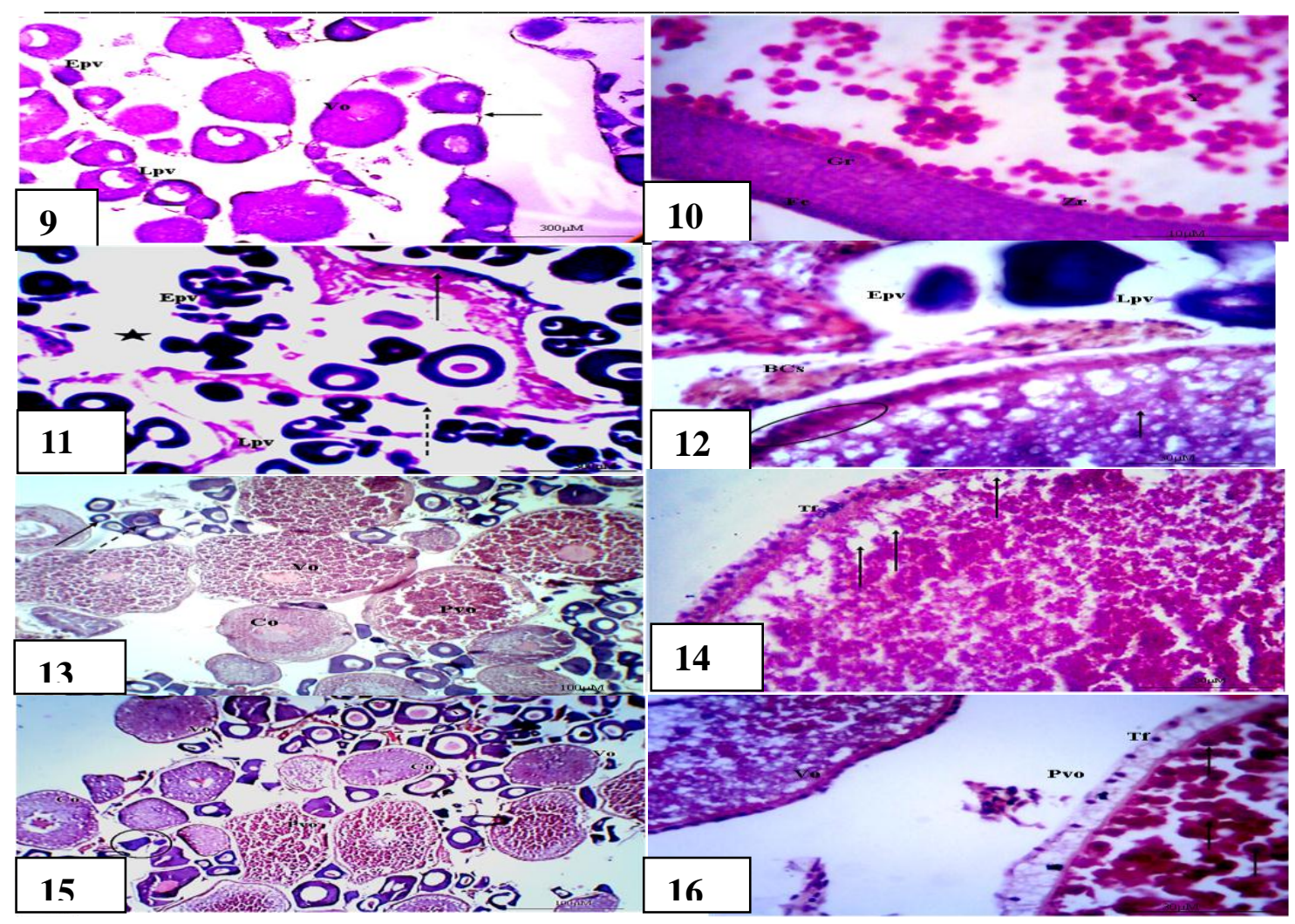

Figs.9-10: Light micrographs of standard ovary section (H\&E stain) showing:

Fig. 9: deformed early pre-vitologenic (Epv), vacuolated late pre-vitologenic (Lpv), atretic vitellogenic oocytes (Vo), tunica albuginea (arrow). Fig. 10: post vitellogenic oocytes with aggregated yolk globules, lysis zona radiate $(\mathrm{Zr})$, abnormal thickness of granulose layer $(\mathrm{Gr})$, thin follicular epithelium (fe).

Fig. 11-12: Light micrographs of exposed for 60 days to pollution (H\&E stain) showing: Sub-group A

Fig. 11: few stages include early pre-vitologenic (Epv), late pre-vitologenic (Lpv), collapsed atretic follicle (arrow), loose tunica albugenia (dashed arrow) and wide inter-follicular space (asterisk). Fig. 12: blood congestion (BCs), necrotic early (Epv), late (Lpv) pre-vittelogenic oocytes, vitologenic oocyte with rare yolk globules (arrow), vague theca follicle (circle).

Figs. 13-14: Light micrographs of ovary sections exposed to pollution + low dose DMSA for 60 days (H\&E stain) showing: Sub-group B

Fig.13: moderate improved ovary with different stages of ovary oocytes, early pre-vitologenic (arrow), late previtologenic (dashed arrow), cortical follicle (Co), deformed vitologenic follicles (Vo) and atretic post-vitologenic oocytes (Pvo).Fig. 14: Part of improved vitologenic oocytes with reformed yolk globules, disappearance of germinal vesicle, well developed theca folliculi (Tf) and few cortical alveoli (arrows)

Figs. 15-16: Light micrographs of ovary sections exposed to pollution + high dose DMSA for 60 days (H\&E stain) showing: Sub-group C

Fig. 15: Well improved ovary have early pre-vitologenic with small cytoplasmic volume (circle), many late previtologenic (dashed circle), abundant cortical follicles (Co) with cortical alveoli, vitologenic oocytes (Vo), postvitologenic oocytes (Pvo).Fig. 16: Part of well improved vitellogenic oocytes (Vo) and post- vitellogenic oocytes (Pvo) with consequence of yolk accumulation (arrows) and hydration of theca folleculi (Tf). 
The examination of vitologenic oocyte showed yolk globules frequently fill the entire center of the oocyte alternated with cortical alveoli at different levels of the ooplasm and coated by demarcated theca folliculei which consisted of follicular epithelium, granulosa and zona radiata well attached to the basement membrane of the oocyte. The post vitologenic oocytes before ovulation are filled with a large number of yolk granules, broken germinal vesicles, hydration, and breakdown of tri-layered theca folliculi (Fig. 16).

\section{Testes}

The standard testes section showed histopathological changes include: multiple focal areas of necrosis and degenerative changes in the cellular elements of most seminiferous tubules, poorly organized lobule structure with diminished number of spermatozoa, where there was a variable amount of spermatozoa from completely disappearance to moderate and desquamation of germ cells (Fig.17), degenerative seminiferous tubules with thick lobular wall as a result of intensive fibrosis and contained few cysts of spermatogenetic elements include degenerative spermatogonia, primary, secondary spermatocytes and spermatozoa (Fig.18) .

Testes sections from sub-group A showed malformations and distortion of the architecture of seminiferous tubules with some tubules revealed few sperms or appeared lucent in between thick interstitial tissue (Fig.19). The raptured testicular tubule forced spermatozoa to move to the wide interstitial space. Shrinked spermatogonia, less number of $1^{\text {ry }}$ spermatocytes with condensed nuclei, and few spermatozoa were observed (Fig.20).

Testes sections from sub-group B showed less to moderate improvement in the histopathological picture when compared with other previous groups (Fig. 21). Improved testes histoarchitecture expressed seminiferous tubule with spermatozoa have dense nucleus side by side with empty one (Fig. 22).

Testes section from sub-group $\mathrm{C}$ showed a nearly normal histological characteristic of both the seminiferous tubule and interstitial space. The examined sections revealed apparent seminiferous tubules supported by thin connective tissue accompanied by more amounts of spermatozoa (Fig. 23).Well-organized tubules with all developmental stages were packed with sperm masses and the interstitial tissue became distended (Fig. 24). 


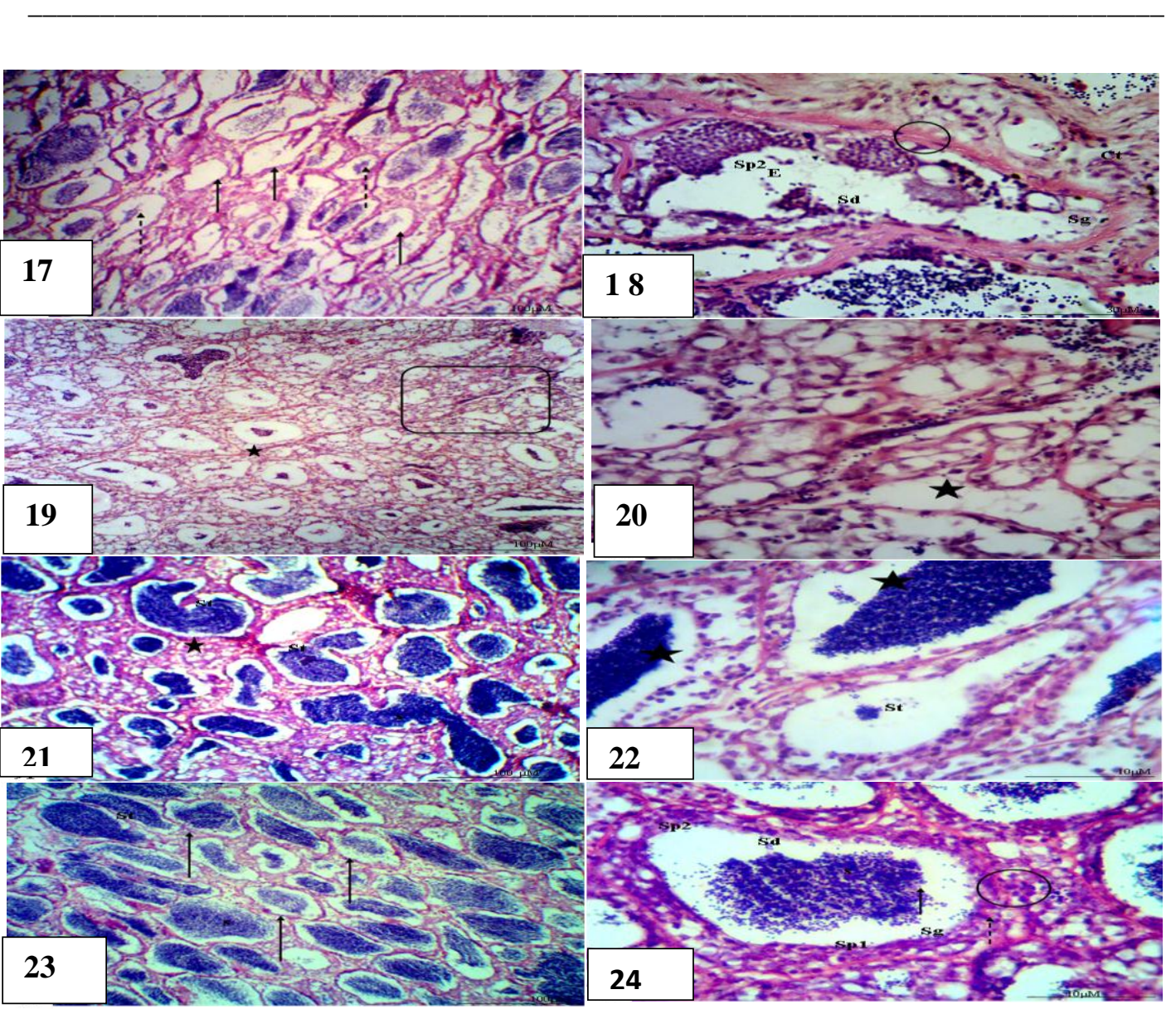

Figs.17-18: Light micrograph of standard testes section (H\&E stain) showing:

Fig. 17: Poorly organized lobule structure (arrows), degenerated seminiferous with diminished spermatozoa (dashed arrow). Fig. 18: Deformed seminiferous tubule with thick wall (circle), degenerated spermtaogonium (Sg), secondary spermatocytes (Sp2), spermatids (Sd), empty testicular lobules (E), interstitial tissue (Ct).

Fig.19-20: Light micrographs of testes sections exposured to pollution for 60 days (H\&E stain) showing: Subgroup A

Fig. 19: Completely disorganized tubule with reduction in both size and spermatogenic masses, wide interstitial tissues (asterisk).Fig. 20: Enlarged part of figure 19 (square): highly vacuolated lobule, few germinal cells, ruptured tubule (arrow), vacuolated interstitial tissue (asterisk).

Figs.21-22: Light micrographs of testes sections exposed to pollution + low dose DMSA for 60 days (H\&E stain) showing: Sub-group B

Fig. 21: moderate improved seminiferous tubules (St), less wide connective tissue (star), more spermatozoa (s). Fig. 22: Seminiferous tubules with variable amount of spermatozoa (asterisk) and still affected seminiferous tubule with empty lumen (ST).

Figs.23-24: Light micrographs of testes sections exposed to pollution + high dose DMSA for 60 days (H\&E stain) showing: Sub-group C

Fig. 23: well organized seminiferous tubules (St), spermatozoa (s) ,narrow connective tissue (arrows).Fig.24: Seminiferous lobules with sperm masses, normal spermatogonia (Sg), primary (Sp1), secondary spermatocytes (Sp2), spermatids (arrow), spermatozoa (s), Leydig cells(circle). 


\section{DISCUSSION}

In various fish species, protein is of importance as a structural compounds, biocatalysts and hormones to control the growth and differentiation. So variation in fish proteins could be used as a bioindicator for monitoring the physiological status of the tested fish (Arafa and Ali, 2008). Water is essential for all living systems. Body fluids act as a medium of transport of nutrients, metabolites, etc. the major component in these fluids is water. It is important for the normal functioning of a lot of biological molecules. The water in the flesh is present in two forms in the tissues, bound to the proteins and in the free form (Authman et al., 2013). Lipids are important metabolite for locomotory and reproductory activities of fish (Zaghloul et al., 2007).

The present findings revealed that the total muscle protein was decreased in the unexposed DMSA group. On the other hand, total lipid content and water content were increased in the unexposed DMSA group. Alterations in total muscle protein and total lipids may be attributed to the change in water quality by the action of pollutants and heavy metals that may critically influence the growth rate and the quality of fish as reported by Elghobashy et al. (2001). The decrease of musculature protein concentration may be due to consuming the protein in energy production under the conditions of heavy metal stress in Lake Maryout. The depletion in lipid and protein contents in musculature may be due to their utilization in cell repair and tissue organization with the formation of lipoproteins, which are important cellular constituents of cell membranes and cell organelles present in the cytoplasm (Palaniappan and Vijayasundaram ,2009).

Mohamed and Gad (2005) recorded a non-significant decrease in the total protein content in the fish muscle collected from Abu Za'baal Lakes as compared with the control values. The muscle lipid content showed highly significant increases in $O$. niloiiciis and $T$. zillii. Arafa and Ali (2008) found that the concentration of protein and lipids of Oreochromis niloticus flesh, exposed to some heavy metals like lead in Lake Maryout was significantly decreased compared with the fish of the reference aquaculture.

Moreover, Authman et al. (2013) stated that the muscle total protein contents of fish collected from El-Rahawy drain showed a highly significant decrease, while muscles water content was increased as compared with the values of the river Nile fish. Awad Elkareem et al. (2014) reported that a significant difference $(\mathrm{P}<0.05)$ was evident in the protein content of fishes Clarias lazera (Cuvier and Valenciennes) reared in the discharge canal of Soba wastewater treatment station, South Khartoum, Sudan. Yousafzai and Shakoori (2009) stated that the muscles showed an increase in total muscle proteins $(11.8 \%$ and $89.6 \%$ ), total lipid (406.8\% and 119.6\%) in Torputitora netted from polluted part of River Kabul. Also, they suggested that the increase in total protein contents showed the acceleration of protein synthesis under the influence of toxicants in response to the stress situation. 
In the present study, DMSA exposed groups showed a significant decrease in water and lipid content in the high dose DMSA exposed group. While the protein showed a significant increase in DMSA exposed groups than unexposed ones. It was concluded that the increase of musculature protein and water percentage and a decrease in lipid concentration after fish exposed to DMSA may be attributed to the role of antidote DMSA, which has removed the toxic effect of lead and mercury in the tissues. Histopathology of fish is not only used as a standard tool for monitoring aquatic environmental changes, but rather it is considered for inclusion as a viable tool for determining fish health, both in the laboratory (Camargo et al., 2009) and field studies (Mohamed, 2009). In this study, standard fish showed both proliferative and necrotic changes in the epithelium of gill filaments and secondary lamellae. Also, variable thickening of primary lamellae, consequent moderate or complete fusion, along with the entire length of secondary lamellae as a result of hyperplasia of inter-lamellar epithelium resulting in a reduction in the surface area and aggregations of inflammatory cells in gill filaments.

The fusion of some secondary lamellae had their effect on reduction in gas, ion exchange and apparent gill surface area which led to the maximum rate of uptake. Less number of holes observed in the primary gill lamellae and the fusion of secondary lamellae might be the result of the disturbance in osmoregulation and ion transport function of the gills (Palaniappan et al., 2008). These alterations might be examples of defense mechanisms because the lifting lamellar epithelium and edema increased the distance between the external environment and the blood, thus serving as a barrier to the entrance of contaminants (Fernandes \& Mazon, 2003). Sayed et al. (2012) showed in some gills of adult Clarias gariepinus exposed to $0.05 \mathrm{mg} / \mathrm{l}$ 4-nonylphenol epithelial lifting, edema, deformed secondary lamellae while in fishes exposed to $0.08 \mathrm{mg} / \mathrm{l}$ 4-nonylphenol, desquamation, and necrosis. In fishes exposed to $0.1 \mathrm{mg} / \mathrm{l} 4$-nonylphenol for 15 days recorded gills with degeneration of cartilaginous bar ,malformed secondary lamellae, increase in chloride cell size and number, epithelial hyperplasia, diffusion of secondary lamellae and increase number of mucous cells. Al-Balawi et al. (2013) found that the gills of the fish Clarias gariepinus exposed to lead acetate suffered from apparent epithelial hypertrophy and epithelial lifting with degeneration of both cytoplasm and secondary lamellae. Chourpagar and Kulkarni (2014) reported that vacuolization in the gill stem, gill lamellae ruptured, connective tissue cells in the stem damaged, destructed and congestion of haemocytes in the gill lamellae are observed in the freshwater female crab, Barytelphusa cunicularis (Westwood) exposed to mercuric chloride.

Several chelating agents approaches have been proposed therapeutically, including supplementation with antioxidants and up-regulation of the endogenous anti-oxidative defense system for heavy metals induced oxidative stress in various body organs (AbdElghaffar et al., 2015). According to Flora et al. (2011), DMSA is an effective chelator of lead and mercury. 
The present results proved that DMSA act as an antioxidant in recovering after heavy metal contamination on dose-dependent .With DMSA low dose, improved gill tissues with organized pillar cell system were recorded while with DMSA high dose; there was no secondary lamellae fusion. Also, the primary and secondary lamellae were identical. Palaniappan et al. (2008) proved that the treatment with DMSA brought in spectacular changes in the gills: there was no fusion of secondary lamellae and the primary and secondary lamellae were distinctly identical. Palaniappan and Vijayasundaram (2009) recorded that DMSA treatment reduces the toxic effects and helps the recovery of gill tissues to return to its control level.

In this study, the most common alterations resulting in ovaries of standard animals are: lytic ovary with many early pre-vitologenic oocytes underwent wrinkling, vacuolated late pre-vitologenic oocytes, irregular cortical oocyte, degenerative vitologenic oocyte with degenerated basement membrane and atretic post-vitologenic oocytes. More alteration occurred in unexposed DMSA group as deformed ovary with few stages of ovary oocytes, wide inter-follicular, hemorrhage between oocytes and vitologenic oocyte with rare yolk globules.

Wahbi and El-Greisy (2007) recorded that in females Siganus rivulatus, effluents (industrial, mixed and domestic) resulted in extensive necrosis of oolema, hypertrophy and hyperplasia of the follicular cells of oocytes. Also, ovaries showed atresia in the large vacuolated mature follicles where atresia characterized by broken zona radiata, a proliferation of follicular cells and break down of yolk granules. Abou Shabana et al. (2008) observed that oogenesis is disrupted on applying concentrations $(3.12 \%, 6.25 \%$ $\& 12.5 \%)$ for, 7, 14 and 28 days to the wastewater effluent. Atretic oocytes and degenerated follicles are observed lead to the absence of ripe oocytes. Nuclear disintegration is detected in perinucleolus oocytes, infiltration of blood tissue which disturbs the development of chromatin nucleolus and perinucleolus oocytes. While, exposure to low concentration doses for short duration resulted in nuclei disintigraion, pycnosis in perinucleolus oocytes and hyperplasia of granulosa layer and zona radiata. Mokhtar and Abd-Elhafeez (2013) reported that lead -induced significant atresia in ovaries especially older oocytes. ElMorshedi et al. (2014) studied the ovaries of Liza ramada from Lake Manzalah which showed atresia (degeneration), necrotic oocytes, a distinctive yolk, vacuolated cytoplasm, broken tunica albuginea.

In this study, exposure to low dose DMSA showed moderately improved ovary with some stages of ovary oocytes appeared. Also, the ovaries of the female Clarias lazera in high dose DMSA group showed synchronous development of improved stat includes: early pre-vitologenic with small cytoplasmic volume, many late pre-vitellogenic, abundant cortical follicles with alveoli at different levels of the ooplasm, vittellogenic follicles includes yolk bodies frequently fill the entire center and coated by demarcated theca folliculi, post vitellogenic oocytes with a large number of yolk granules. The positive effect 
of DMSA may be attributed to its properties as a chelating agent (Flora et al., 2008). DMSA has been recommended for the treatment of lead and mercury in human (Masters $\boldsymbol{e t}$ al., 2008).

The present standard group showed multiple focal areas of necrosis and degenerative changes in the cellular elements of most seminiferous tubules led to poorly organized lobule structure with diminished spermatozoa. While testes exposed to pollution for 60 days showed extra histopathological effects as, ruptured basal lamina, lytic interstitial tissue, scattered a fewer number of $1^{\text {ry }}$ spermatocytes, shrunk spermatogonia, and a decline in spermatogenic cell and sperm density.

The reproductive toxicity resulted from high dose lead exposure (Lowry, 2010), as the first target of heavy metals are the gonads, caused a wide spectrum of male and female reproductive systems consequence reduced fertility (Flora $\boldsymbol{e t}$ al., 2011) where there is a direct action of heavy metals on the gonads (Shalaby and El Migeed., 2012). Experimental studies showed that lead and mercury caused suppression of spermatogenesis in rats depending on the dose-quantity so, sperm production rate and fertility decreased (EISayed $\boldsymbol{e t}$ al., 2015). The marked inhibition in the process of spermatogenesis due to $\mathrm{Cd}$ and $\mathrm{Pb}$ pollution simulates with that described by Kuz'mina, (2011) who found a decline in the gonadal activity as reflected by decreasing of sperm amount in the ripe testis of Cyprinus carpio. Shalaby and Abd-El Migeed (2012) studied the histological examination of the testes of $O$. niloticus from Lake Manzala and they found that degenerative germinal epithelium of the seminiferous tubules, vacuolization in proliferating germ cells; decline in spermatogenic cell and sperm density. El-Morshedi $\boldsymbol{e t}$ al. (2014) studied the effects of heavy metals of Lake Bardawil on Liza ramada testes; they showed a decreased number of seminiferous tubules along with some degenerative changes. They appeared empty from primary and secondary spermatocytes. The interstitial cells and Sertoli cells had invaded all seminiferous tubules sperm nests. Accordingly, seminiferous tubules showed the lesser number of spermatids which had a radiated shape without any inner septa between nests. El-Sayed et al. (2015) showed that lead acetate caused necrosis of spermatogenic cells in the rat's seminiferous tubules, congestion of interstitial blood vessels and severe interstitial edema.

DMSA has dual function as antioxidant and chelating agent supporting by Flora $\boldsymbol{e t}$ al. (2008) and possible efforts of chelating agents like DMSA as antidote metal poisoning were done (Flora $\boldsymbol{e t} \boldsymbol{a l . , 2 0 1 1 )}$ and this agrees with the present study where less to moderate improvement in the histopathological picture was noticed in low dose exposed DMSA group. The examined sections revealed apparent seminiferous tubules supported by thin connective tissue accompanied by different types of germ cells and more amounts of spermatozoa. More improvement with high dose where seminiferous lobules were packed with, Sertoli cell and sperm masses and these improvements were agree with El-Sayed $\boldsymbol{e t}$ al. (2015) who showed that DMSA (50 mg/kg b.w /week) for 6 weeks improved partially 
the toxic effect of lead on the rat testis and leads to mild necrosis of some seminiferous tubules, mild congestion of interstitial blood vessels and mild interstitial edema. The impacts of DMSA not only in preventing the lead and mercury toxicity but a new and better approach to treating cases of metal poisoning (Flora et al., 2008).

In conclusion, this study showed that DMSA is a powerful therapy to overcome lead and mercury toxicity in fish tissues. It appears that the protective effect of DMSA may be attributed to its activity as a chelating agent with at least two negatively charged groups that allow it to form complexes with metal ions have multiple positive charges, such as lead, mercury, and reactive oxygen species.

\section{REFERENCES}

Abd-Elghaffar, S.K.H.; El-Sayed, M.F.; Adly, M.A. and Abdel-Samei, W.M. (2015). The protective effects of DMSA and some vitamins against toxicity induced by lead in male Albino rats. J. Pharm. Appl. Chem. 1(1): 1-8.

Abou Shabana, N.M.; Abdel-Moneim, A.M.; Khadre, S.E.M; and Elalkamy, H.H. (2008). Histological alterations in gonads of (Clarias lazera) after exposure to dyestuff and chemicals waste water effluent. Egypt. J.Aquat.Res. 34: 351-368.

Abumourad, I.M.K.; Mohammad, M.N. and Abbas, W.A.T. (2013). Heavy Metal Pollution and Metallothionein Expression: A Survey on Egyptian Tilapia Farms. J. Appl.Sci. Res. 9 (1): $612-619$.

Al-Balawi, H.F.A.; Al-Akel, A.S.; Al-Misned, F.; Suliman, E.M.; Al-Ghanim K. A.; Mahboob, S. and Ahmad, Z. (2013). Effects of sub-lethal exposure of lead acetate on histopathology of gills, liver, kidney and muscle and its accumulation in these organs of (Clarias gariepinus). Brazil. Arch. Biol. Tech. 56(2): 293-302.

Arafa, M.M. and Ali, A.T. (2008). Effect of some heavy metals pollution in Lake Mariout on (Oreochromis niloticus) fish. Egypt. J. Comp. Path and Clin.. Path 21(3), 191 - 201.

Authman, M.M.N.; Ibrahim, S.A.; El-Kasheif, M. A. and Gaber, H. S.(2013) Heavy Metals Pollution and Their Effects on Gills and Liver of the Nile Catfish Inhabiting El-Rahawy Drain, Egypt. Global Veterinaria. 10 (2): 103-115.

Awad Elkareem, M.M.A.; Karrar, A.M.H. and Ali, A.K.S. (2014). Relationship of biometric size-weight, nutritive value, and metal concentrations in (Clarias lazera) (Cuvier and Valenciennes) reared in treated waste water. 7(3): 217 - 225.

Bancroft, J.D. and Gamble, M. (2002). Theory and practice of histological techniques. Neuro. J \& Exp. Neuro. 67(6):633. 
Bradberry, S. and Vale, A. (2009). Dimercaptosuccinic acid (succimer; DMSA) in inorganic lead poisoning. Clin Toxicol (Phila). 47(7):617-31.

Camargo, M.M.P.; Fernandes, M.N. and Martinez, C.B.R. (2009). How aluminium exposure promotes osmoregulatory disturbances in the Neotropical freshwater fish (Prochilus lineatus). Aquat. Toxicol. 94: 40-46.

Chourpagar, A.R. and Kulkarni, G.K. (2014). Effect of mercuric chloride on gill structure of a freshwater female crab, Barytelphusa cunicularis (Westwood). J.Glob.Biosci. 3(2):423-427.

Damian, E.C.; Afulenu, N.L.; Obinna, O.M. and Ndidi, O.C. (2014). Bioaccumulation of heavy metals in fish sourced from environmentally stressed axis of River Niger: Threat to ecosystem and public health. In. J. Enviro. Prot. Pol. 2(4): 126-131.

Doughaday, W.H.; Lowry, O.H. and Rosebrugh, N.J. (1952). Determination of cerebrospinal fluid protein with the folinephenol reagent. J. Lab. Clin. Med. 39: 663-665.

El-Boshy, M.E.; Gadalla H.A. and Abd El-Hamied, F.M. (2014). Immunological, hematological and biochemical changes induced by short term exposure to cadmium in catfish (Clarias gariepinus). J. Coast. Life Med. 2(3): 175-180.

Elghobashy, H.A.; Zaghloul, K.H. and Metwally, M.A.A. (2001). Effect of some water pollutants on the Nile tilapia, (Oreochromis niloticus) collected from the river Nile and some Egyptian Lakes. Egypt. J. Aquat. Biol. Fish. 5(4): 251-279.

El-Morshedi, N.; Alzahrani, I.; Kizilbash, N.A., Abdeen, A.; El-Shebbly, A.A. and El-Berri, A. (2014). Effect of heavy metal pollutants on fish population in two Egyptian Lakes. Int. J. Adv. 2(1): 408-417.

El-Sayed, M.F.B.; Sary, K.H.; Abdel-Ghafar, A.; Adly, M.A.; Salim, A.A. and Abdel-Samei, W.M. (2015). The ameliorative effects of DMSA and some vitamins against toxicity induced by lead in the testes of Albino rats. J. Basic. Appl. Zool. 71: 60-65.

El-Shehawi, A.M.; Ali, F.K. and Seehy, M.A. (2014). Estimation of water pollution by genetic biomarkers in tilapia and catfish species shows species-site interaction. Afri. J. Biotech. 6(7): 840-846.

Fernandes, M.N. and Mazon, A.F. (2003). Environmental pollution and fish gill morphology. In: Val, A.L. and B.G. Kapoor (Eds.). Fish adaptation Enfield, Science Publishers. 203-231.

Flora, S.J.S; Mittal, M. and Mehta, A. (2008). Heavy metal induced oxidative stress \& its possible reversal by chelation therapy. Indian. J. Med. Res.128: 501-523.

Flora S.J.S. and Pachauri, V. (2010). Chelation in metal intoxication. Int J Environ Res Public Health. Jul. 7(7): 2745-2788. 
Flora S.J.S. Mittal, M. and Mehta, A. (2011). Arsenic, cadmium and lead. In: Reproductive and Developmental Toxicology. Acad. Press. 415-438.

Knight, A.; Anderson, S. and Rowle, J.M. (1972). Chemical basis of the sulfophosphovanillin reaction of estimating of total serum lipids. Clin. Chem. 75(3): 199

Kuz'mina, V.V. (2011). The influence of zinc and copper on the latency period for feeding and the food uptake in common carp, Cyprinus carpio L. Aquat. Toxicol. 102: 73-78.

Lowry, J.A. (2010). Oral chelation therapy for patients with lead poisoning. Division of Clinical Pharmacology and Medical Toxicology.

Mary, C.H.S.; Silvan, S. and Elumalai, E.K. (2014). Toxicology study on lead nitrate induced fresh water fish Cirrhinus mrigala (Hamilton). Europ. J. Acad. Essay. 1(7): 5-8.

Masarat, J.; Borana, K. and Sujaad, N. (2014). Effect of mercuric chloride on histology of ovaries of Africcan catfish, Clarias gariepinus. Int. J. Res. App. 2(5):107-110.

Masters, S.B.; Trevor, A.J. and Katzung, B.G. (2008). Katzung \& Trevor's Pharmacology: Examination \& Board Review (8th Ed.). McG. H. Med. 481-3.

Mohamed, F.A.S. (2009). Histopathological studies on (Tilapia zillii and Solea vulgaris) from Lake Qarun, Egypt. W. J. Fish. Mar. Sci. 1 (1): 29-39

Mohamed, F.A.S. and Gad, N.S.H. (2005). Distribution of some heavy metals in tissues of (Oreochroms siloticus, Tilapia zilli and Clarias lazera) from abu za'baal Lakes and Their impacts on some biochemical parameters and on the histological structures of some organs. Egypt j. Aquau. biol.

Mokhtar, D.M. and Abd-Elhafeez, H.H. (2013). Histological changes in selected organs of (Oreochromis niloticus) exposed to doses of lead acetate. J. Life Sci. Biomed. 3(3): 256-263.

Palaniappan, R.M.; Sabhanayakam, S.; Krishnakumar, N. and Vadivelu, M. (2008). Morphological changes due to lead exposure and the influence of DMSA on the gill tissues of the freshwater fish (Catla catla). Food. Chem. Toxicol. 46.

Palaniappan, R.M. and Vijayasundaram, V. (2009). The effect of arsenic exposure and the efficacy of DMSA on the proteins and lipids of the gill tissues of (Labeo rohita). Food. Chem. Toxicol. 47:1752-1759.

Pugazhvendan, S.R.; Mariappan, M.; Leon, P.S. and Balakrishnan, J.K. (2012). Bioaccumulation of lead in fresh water fish (Cyprinus Carpio). Int. J. C. Res. 4 (7):146-148.

Raafat, M.; El-Barbary, A.; Touson, E. and Aziz, S. (2011). Dimercapto succinic acid (DMSA) and vitamin $\mathrm{C}$ chelating potency in lead intoxication, regarding oxidative stress and apoptotic proteins in rabbit. J. Gen. Engin. Biotech. 9:121-131.

Saad, M.A.H. (2003). Impact of diffuse pollution on the socio-economic development opportunities in the coastal Nile delta Lakes. Diffuse pollution conference Dublin ECSA 5: Management. 
Sayed, A.H.; Mekkawy, I.A. and Mahmoud, U.M. (2012). Histopathological alterations in some body organs of adult (Clarias gariepinus) exposed to 4-Nonylphenol, Zoology, Dr. MaríaDolores García (Ed.).

Selvanathan, J.; Vincent, S. and Nirmala, A. (2012). Histopathology changes in fresh water fish (Clarias batrachus) exposed to mercury and cadmium. Int. J. Pharm. 3(4): 422-428.

Shalaby, F.M. and Migeed, H.A.E. (2012). Impact of environmental contaminants on the testes of (Oreochromis niloticus) with special reference to ultrastructure of spermatozoa in Lake Manzala (Egypt). J. Environ. Anal. Toxicol. 2:149.

Sidwell, V.D.; Stillings, B.R. and Knoble, M. (1970). The fish protein concentration. Nutritional quality and using fish In foods. J. Food.Technol.14: 40-46.

Siraj, M.; Shaheen, M.; Sthanadar, A.A.; Khan, A.; Douglas, P.; Chivers, A.M. and Yousafzai. (2014). A comparative study of bioaccumulation of heavy metals in two fresh water species (Aorichthys seenghala and Ompok bimaculatous) at River Kabul, Khyber Pakhtunkhwa, Pakistan J. Bio. Env. Sci. 4(3):40-54.

Yousafzai, A.M. and Shakoori, A.R. (2009). Fish white muscle as biomarker for riverine. Pollution Pakistan. J. Zool. 41(3):179-188.

Wahbi OM and El-Greisy ZA (2007). Comperative impact of different waste sources on the reproductive parameters and histology of gonads, liver and pituitary gland of Siganus rivaltus J. App. Sci. Res 3 (3), 236-244

Zaghloul, K.H.; Hasheesh, W.S.; Zahran, A.; Mohamed-Assem, S. and Marie. (2007). Ecological and biological studies on the Nile tilapia (Oreochromis niloticus) along different sites of Lake Burullus. Egypt. J. Aquat. Biol. and fish. 11(3): 57 - 88. 